\title{
A Comparative Study of the Nonlinear Methods for Estimating Body Weight Based on Body Measurements in Different Sample Sizes in Morkaraman Sheep
}

\author{
Aycan Mutlu YAĞANOĞLU 1,a (*)
}

\author{
${ }^{1}$ Ataturk University, Faculty of Agriculture, Department of Animal Science, TR-25240 Erzurum - TÜRKIYE \\ ORCID: ${ }^{\text {a } 0000-0002-0163-6989 ~}$
}

\section{Article ID: KVFD-2021-26864 Received: 28.11.2021 Accepted: 27.02.2022 Published Online: 28.02.2022}

\begin{abstract}
The objective of this study is to estimate the body weight of Morkaraman sheep from body measurements with nonlinear models. Five different models (allometric, logistic, saturation growth, exponential and incomplete gamma) are used to estimate best-fitted model for relationship between body length and body weight of Morkaraman sheeps at different sample sizes. Selected 110 sheeps 3-5 years were scored for body weight, body length, height at wither, chest width and rump width. For determining the relationships with body weight between body measurements, correlation analysis was performed. The results of the correlation analysis indicated that the highest relationship according to all sample sizes was between body weight and body length $(0.95,0.90,0.83,0.81)$. Considering all parameters included in the model, the parameter showing the highest correlation with body weight was determined as body length according to all sample sizes. The highest correlation was found in 50 sample sizes ( $\mathrm{r}=0.95)$. According to the small sample sizes (10-20), Logistic and Saturation growth models can be used to determine the body weight by using body length, on the other hand, the Incomplete gamma model is more successful to estimate body weight when the sample size is nearly 30 and 50.
\end{abstract}

Keywords: Body measurements, Morkaraman, Logistic, Saturation growth, Incomplete gamma

\section{Morkaraman Koyunlarında Farklı Örnek Büyülklülklerinde Vücut Ölçülerine Göre Vücut Ağırlığının Tahmin Edilmesinde Doğrusal Olmayan Yöntemlerin Karşılaştırılması}

\begin{abstract}
Öz: Bu çalışmanın amacı, Morkaraman koyunlarının vücut ağırlığının lineer olmayan modellerle vücut ölçülerinden tahmin edilmesidir. Farklı örneklem büyüklüklerinde Morkaraman koyunlarının vücut uzunluğu ve vücut ağırlığı arasındaki ilişki için en uygun modeli tahmin etmek için beş farklı model (allometric, logistic, saturation growth, exponential and incomplete gamma) kullanılmıştır. Üç ile beş yaş arası seçilen 110 koyunun, vücut ağırlığı, vücut uzunluğu, cidago yüksekliği, göğüs genişliği ve sağrı genişliği değerleri ölçülmüştür. Vücut ölçüleri arasında vücut ağırlı̆̆ı ile ilişkileri belirlemek için korelasyon analizi uygulanmıştır. Korelasyon analizi sonuçları, tüm örneklem büyüklüklerine göre en yüksek ilişkinin vücut uzunluğu ile $(0.95,0.90,0.83,0.81)$ vücut ağırlığı arasında olduğunu göstermiştir. Modelde yer alan tüm parametreler dikkate alındığında, örneklem büyüklüklerine göre vücut ağırlı̆ğ ile en yüksek korelasyonu gösteren parametre vücut uzunluğu olarak belirlenmiştir. En yüksek korelasyon 50 örneklem büyüklüğ̈̈nde bulunmuş olup ( $\mathrm{r}=0.95)$, küçük örneklem boyutlarına göre (10-20), vücut uzunluğunu kullanarak vücut ağırlığını belirlemek için Lojistik ve Saturation Growth modelleri, örnek büyüklüğü yaklaşık 30-50 arasında olanlarda ise vücut ağırlı̆̆ını tahmin etmede Incomplete gama modeli daha etkili sonuçlar vermiştir.
\end{abstract}

Anahtar sözcükler: Vücut ölçüleri, Morkaraman, Logistic, Saturation growth, Incomplete gamma

\section{INTRODUCTION}

The increase in the number and size of cells in certain time intervals in accordance with the type of animal, shaped by the interaction of the genetic structure of living things and the environmental conditions in which they are found, is expressed as growth ${ }^{[1]}$.

Macedo-Barragán ${ }^{[2]}$ concluded that as an alternative to linear models, incomplete gamma and exponential models

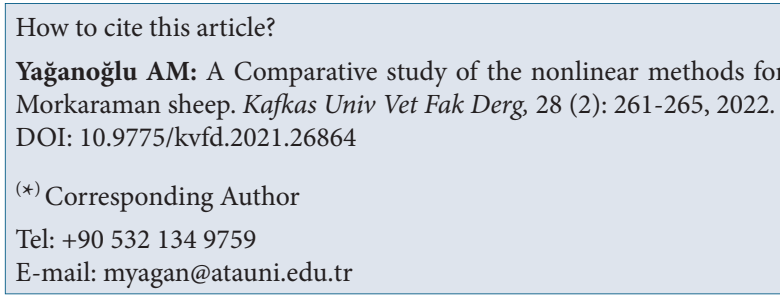


can be used to predict body weight of sheep using some body measurements.

Selection of the appropriate model requires a statistical decision process, since the live weight varies according to the species, environmental conditions and the trait studied. It has been reported in the literature that although a constant rate of weight gain occurs in certain periods for some characteristics of some living things, the weight increases in living things is not constant throughout their lifetime ${ }^{[3-5]}$.

Linear models are often insufficient to model the growth of living things over the lifespan ${ }^{[4-6]}$. In the case of periods of different growth rates, it is useful or even necessary to use non-linear models, which are slightly more complex than linear models.

Tahtali et al. ${ }^{[7]}$ aimed to model the body weight gains of Romanov lambs and individual growth curves using different equations. Cubic spline model, Logistic model, Gompertz model and Richard models were used as models in the study.

The determination and estimation of non-linear models are more difficult than linear models, and the results are determined iteratively using different methods ${ }^{[8]}$.

In this study, it was tried to determine a model that gave the best fit between body weight and body measurements in different sample sizes. Although these measured variables can be explained by linear models, they can also be explained by nonlinear models. For this purpose, although the variables used in this study are in linear form, nonlinear regression models can also be used for this purpose. In this study, it is aimed to determine nonlinear regression models as an alternative to linear regression models.

\section{Material ANd Methods}

\section{Materials}

The data used in this study were recorded on 110 Morkaraman sheep maintained in Atatürk University, Food and Livestock Research and Application Center. Body measurements of adult animals aged 3-5 years were recorded using a graduated measuring tape. Whole body measurements were taken with the animal standing, head up and weight on all fours without body movement. Body weight was taken using a suspended digital scale. Sheeps were included in the study as 10,20, 30 and 50 separately according to sample size.

\section{Methods}

Correlation coefficients were used to determine the relationship between parameters. In addition, it is aimed to determine the best model according to the sample size in determining the live weight by using the nonlinear models.

The models were tested for goodness of fit by the (MSE) Mean Square Error and $\left(\mathrm{R}^{2}\right)$, adjusted coefficient of determination $\left(\mathrm{R}^{2}{ }_{\text {adj }}\right)$, Akaike information criterion (AIC), Bayes information criterion (BIC) and mean squared prediction error (MEP). The statements of these evaluators are also presented in detail in Silveira et al. ${ }^{[9]}$.

\section{RESULTS}

Considering all parameters included in the model, the parameter showing the highest correlation with body weight was determined as body length according to all sample sizes. As indicated in Table 1, the highest correlation was found in 50 sample sizes $(r=0.95)$. This was followed by sample sizes of 30, 20 and 10, respectively. The highest correlations for the BW parameters between BL were found $0.95,0.90,0.83$ and 0.81 , respectively. In addition, the lowest correlation values were between BW and $\mathrm{HW}(\mathrm{r}=0.46), \mathrm{BW}$ and $\mathrm{HG}(\mathrm{r}=0.51)$ and, BW and RW ( $r=0.48)$. Considering all sample sizes, body length was included as an independent variable in nonlinear models.

Table 2 gives the results of nonlinear models, in which five different models for estimating best-fitted model for relationship between body length and body weight of Morkaraman sheeps at different sample sizes.

$\mathrm{R}^{2}$ and MSE values for models estimated by five different models and sample sizes have been used to determine the best fit models.

Considering the sample sizes; the lowest $\mathrm{R}^{2}$ and the highest MSE values occurred in the group with sample size 10. According to this group, the highest $\mathrm{R}^{2}$ value (0.64) was

Table 1. Correlations between body weight and body measurements with different sample sizes

\begin{tabular}{|c|c|c|c|c|c|c|c|}
\hline Body Weight & Sample Size & BL & HD & HW & CW & HG & RW \\
\hline BW & 10 & $0.81^{\star *}$ & $0.57^{\star}$ & 0.46 & $0.73^{* *}$ & 0.51 & 0.48 \\
\hline BW & 20 & $0.83^{* *}$ & $0.72^{*}$ & $0.58^{*}$ & $0.75^{\star *}$ & $0.66^{*}$ & 0.53 \\
\hline BW & 30 & $0.90^{* *}$ & $0.78^{\star *}$ & $0.60^{*}$ & $0.74^{* *}$ & $0.76^{*}$ & $0.61^{\star}$ \\
\hline BW & 50 & $0.95^{* *}$ & $0.81^{*}$ & $0.69^{*}$ & $0.74^{* *}$ & $0.76^{*}$ & $0.66^{*}$ \\
\hline
\end{tabular}




\begin{tabular}{|c|c|c|c|c|c|}
\hline $\mathbf{n}$ & Model & Equation & $\mathbf{P}$ & $\mathrm{R}^{2}$ & MSE \\
\hline \multirow{5}{*}{10} & Allometric & $0.004 \mathrm{BL}^{2.09}$ & 0.035 & 0.59 & 15.18 \\
\hline & Logistic & $196.85 /\left(1+\exp ^{(3.446-0.0512 \mathrm{BL})}\right)$ & 0.020 & 0.64 & 14.98 \\
\hline & Saturation growth & $-19.785 \mathrm{BL} /(-196.71+\mathrm{BL})$ & 0.016 & 0.61 & 14.76 \\
\hline & Exponential & $5.0142 \exp ^{(0.0375 \mathrm{BL})}$ & 0.020 & 0.60 & 14.91 \\
\hline & Incomplete gamma & $0.1014 \mathrm{BL}^{1.214} \exp ^{(0.021 \mathrm{BL})}$ & 0.028 & 0.63 & 14.89 \\
\hline \multirow{5}{*}{20} & Allometric & $0.003 \mathrm{BL}^{2.11}$ & 0.016 & 0.66 & 14.01 \\
\hline & Logistic & $202.45 /\left(1+\exp ^{(3.4141-0.0548 \mathrm{BL})}\right)$ & 0.013 & 0.65 & 14.01 \\
\hline & Saturation growth & $-18.471 \mathrm{BL} /(-188.16+\mathrm{BL})$ & 0.008 & 0.71 & 13.44 \\
\hline & Exponential & $4.7811 \exp ^{(0.0108 \mathrm{BL})}$ & 0.002 & 0.60 & 13.75 \\
\hline & Incomplete gamma & $0.1008 \mathrm{BL}^{1.303} \exp ^{(0.025 \mathrm{BL})}$ & 0.008 & 0.68 & 13.67 \\
\hline \multirow{5}{*}{30} & Allometric & $0.003 \mathrm{BL}^{2.14}$ & 0.012 & 0.74 & 12.11 \\
\hline & Logistic & $201.48 /\left(1+\exp ^{(3.358-0.0442 \mathrm{BL})}\right)$ & 0.008 & 0.79 & 12.02 \\
\hline & Saturation growth & $-20.016 \mathrm{BL} /(-198.34+\mathrm{BL})$ & 0.010 & 0.78 & 12.16 \\
\hline & Exponential & $4.842 \exp ^{(0.0392 \mathrm{BL})}$ & 0.002 & 0.79 & 12.08 \\
\hline & Incomplete gamma & $0.1021 \mathrm{BL}^{1.136} \exp ^{(0.019 \mathrm{BL})}$ & 0.001 & 0.82 & 11.88 \\
\hline \multirow{5}{*}{50} & Allometric & $0.003 \mathrm{BL}^{2.15}$ & 0.003 & 0.88 & 12.02 \\
\hline & Logistic & $199.61 /\left(1+\exp ^{(3.303-0.0398 \mathrm{BL})}\right)$ & 0.001 & 0.89 & 12.00 \\
\hline & Saturation growth & $-20.038 \mathrm{BL} /(-199.16+\mathrm{BL})$ & 0.001 & 0.86 & 12.01 \\
\hline & Exponential & $4.8805 \exp ^{(0.0384 \mathrm{BL})}$ & 0.001 & 0.88 & 12.02 \\
\hline & Incomplete gamma & $0.1019 \mathrm{BL}^{1.149} \exp ^{(0.020 \mathrm{BL})}$ & 0.001 & 0.92 & 11.94 \\
\hline
\end{tabular}

\begin{tabular}{|c|c|c|c|c|c|}
\hline \multicolumn{2}{|c|}{ Table 3. Estimation linear equations for predicting body weight of Morkaraman lambs from body measurements with different sample sizes } \\
\hline $\mathbf{n}$ & Model & Equation & P & $\mathrm{R}^{2}$ & MSE \\
\hline 10 & Linear & BW $=-12.516+0.811 \mathrm{BL}$ & 0.040 & 0.66 & 17.16 \\
\hline 20 & Linear & $\mathrm{BW}=-11.986+0.793 \mathrm{BL}$ & 0.035 & 0.69 & 15.44 \\
\hline 30 & Linear & $\mathrm{BW}=-9.542+0.707 \mathrm{BL}$ & 0.012 & 0.81 & 13.11 \\
\hline 50 & Linear & $\mathrm{BW}=-9.233+0.765 \mathrm{BL}$ & 0.003 & 0.90 & 11.08 \\
\hline
\end{tabular}

determined in Logistic and the lowest MSE value (14.76) was determined in Saturation growth models. When sample size was kept as 20 , the highest $\mathrm{R}^{2}$ value $(0.71)$ and the lowest MSE value (13.44) was detected in Saturation growth models.

Considering the different sample sizes, the results of the linear regression model are given in Table 3. According to these results, the $\mathrm{R}^{2}$ value was 0.66 and the MSE value was 17.16 in the model with a sample size of 10 , and the $\mathrm{R}^{2}$ value was 0.69 and the MSE value was 15.44 in the model with a sample size of 20 . In addition, the $\mathrm{R}^{2}$ value was 0.81 and the MSE value was 13.11 in the model with a sample size of 30 , and the $\mathrm{R}^{2}$ value was 0.90 and the MSE value was 11.08 in the model with a sample size of 50 . According to these obtained values, it was found that as the sample size increased, the $\mathrm{R}^{2}$ value increased and the MSE value decreased. According to different sample sizes, these coefficients showed that there is more similarity between the linear and nonlinear methods.
Table 4 shows the results of the evaluators of goodness of fit $\left(\mathrm{R}_{\text {adj }}^{2}, \mathrm{AIC}, \mathrm{BIC}, \mathrm{MEP}\right)$ for each model. Considering the $\mathrm{R}^{2}$ adj value, the highest value was obtained as Incomplete gamma (0.8464), Logistic (0.7921), Allometric (0.7744) and Exponential (0.7744) with sample size 50. The low MEP values, the lowest values were obtained as Incomplete gamma (10.9096), Exponential (11.0864) and Logistic (11.3212), respectively. The lowest $\mathrm{R}_{\text {adj }}^{2}$ value was obtained as Allometric (0.3481), Exponential (0.3600), Saturation growth (0.3721) and Incomplete gamma (0.3969) with sample size 10. Considering the high MEP values, the highest values were obtained as Incomplete gamma (24.8530), Exponential (24.2070) and Allometric (20.6392), respectively. Considering the AIC value, the lowest value was obtained as Incomplete gamma (175.3682), Logistic (187.7116), Allometric (188.9002) and Exponential (189.4751) with sample size 50 . The lowest BIC values were obtained as Incomplete gamma (182.4006), Exponential (198.6672) and Logistic (202.1524), respectively. 


\begin{tabular}{|c|c|c|c|c|c|}
\hline $\mathbf{n}$ & Model & $\mathbf{R}_{\text {adj }}^{2}$ & AIC & BIC & MEP \\
\hline \multirow{5}{*}{10} & Allometric & 0.3481 & 204.9446 & 219.7146 & 20.6392 \\
\hline & Logistic & 0.4096 & 198.4871 & 213.9151 & 19.7252 \\
\hline & Saturation growth & 0.3721 & 198.4871 & 213.7989 & 15.6051 \\
\hline & Exponential & 0.3600 & 210.0728 & 226.2827 & 24.2070 \\
\hline & Incomplete gamma & 0.3969 & 204.9446 & 220.2445 & 24.8530 \\
\hline \multirow{5}{*}{20} & Allometric & 0.4356 & 198.2946 & 215.0813 & 21.6386 \\
\hline & Logistic & 0.4225 & 210.8582 & 226.7405 & 20.2056 \\
\hline & Saturation growth & 0.5041 & 205.5648 & 222.9836 & 21.3546 \\
\hline & Exponential & 0.3600 & 204.9446 & 222.7792 & 17.3273 \\
\hline & Incomplete gamma & 0.4624 & 208.5478 & 224.3540 & 15.1510 \\
\hline \multirow{5}{*}{30} & Allometric & 0.5476 & 206.7871 & 223.7148 & 16.7722 \\
\hline & Logistic & 0.6241 & 202.1458 & 218.5526 & 14.6922 \\
\hline & Saturation growth & 0.6084 & 199.2580 & 216.1218 & 15.4842 \\
\hline & Exponential & 0.6241 & 197.6542 & 218.8890 & 14.6692 \\
\hline & Incomplete gamma & 0.6724 & 192.8586 & 214.4148 & 12.5628 \\
\hline \multirow{5}{*}{50} & Allometric & 0.7744 & 188.9002 & 202.3128 & 12.2018 \\
\hline & Logistic & 0.7921 & 187.7116 & 202.1524 & 11.3212 \\
\hline & Saturation growth & 0.7396 & 192.1541 & 216.7005 & 13.4086 \\
\hline & Exponential & 0.7744 & 189.4751 & 198.6672 & 11.0864 \\
\hline & Incomplete gamma & 0.8464 & 175.3682 & 182.4006 & 10.9096 \\
\hline
\end{tabular}

\section{Discussion}

Topal and Macit ${ }^{[10]}$ were reported that in their study in 66 Morkaraman sheep, as a result of multiple regression analysis, the $\mathrm{R}^{2}$ value of body length affecting body weight was 0.282 and MSE value was 31.702, respectively. Ibrahim et al. ${ }^{[11]}$ revealed that $\mathrm{CG}$ and its combination with other linear body measurements can effectively define the body weight in Batur sheep. However, the highest $\mathrm{R}^{2}$ of 0.782 was observed when CG and BL were used as predictors. As a result of the different nonlinear models used to estimate the body weight of Morkaraman sheeps, according to the all sample sizes Incomplete gamma model is the most appropriate model when $\mathrm{R}^{2}, \mathrm{MSE}, \mathrm{R}_{\text {adj }}^{2}$ AIC and BIC values were taken into account. Rather et al. ${ }^{[12]}$ were emphasized that the coefficient of determination $\left(\mathrm{R}^{2}\right)$ is succesful to estimate body weight from body measurements in Kashmir Merino sheeps. Considering the sample sizes of 30 and 50 , the highest $R^{2}$ values $(0.82$ $0.92)$ and the lowest MSE values (11.88-11.94) were found in the Incomplete gamma model, respectively. Demir and Sahinler ${ }^{[13]}$ using nonlinear Brody, Bertalanffy, Logistic, Gompertz and Richards models in their study, selected the model with high coefficient of determination $\left(\mathrm{R}^{2}\right)$ and low mean square error (MSE) as the best model to describe growth. In conclusion, Richards and Logistic models were the best predictors of overall growth of lambs in nonlinear models. Among the groups, the lowest MSE and the highest
$\mathrm{R}^{2}$ were obtained in the second group and in the Logistic model. According to this model; $\mathrm{R}^{2}$ and MSE were found to be $0.999 \pm 0.0002$ and $0.41 \pm 0.060$, respectively. MacedoBarragan et al. ${ }^{[2]}$ reported that according to all nonlinear models $\mathrm{R}^{2}$ value is calculated higher than 0.75 for estimating body weight from body measurements.

The nonlinear regression analysis with $\mathrm{R}^{2}$ calculated for growth in Awassi lambs showed that the relationship derived from the regression weight in weight at 6 months at weaning according to the exponential function was considered to be the best since the $\mathrm{R}^{2}$ value was $0.69^{[14]}$.

Bilgin et al. ${ }^{[15]}$ reported that Brody is the best model for describing as unfit between body weight and age in sheeps. And also, body measurement in farm animals is used to decide the apparent identity and growth pattern ${ }^{[16,17]}$.

Raungprim et al. ${ }^{[18]}$ used three nonlinear regression models: exponential, polynomial quadratic and power models to analyze the relationship between body parameters and body weight. As a result, it was revealed that the power model gave the best HG and body weight relationship model with the highest $\mathrm{R}^{2}(0.9662,0.9748$ and 0.9702$)$ respectively in swamp buffaloes. Topuz ${ }^{[19]}$ calculated the mean membership degree (MDM) and mean square error (MSE) as $\mathrm{MDM}=0.896$ and $\mathrm{MSE}=4.871$, respectively, in order to decide the adequacy of the model by using the fuzzy logic approach-based posibilistic logistic regression 
method together with its theoretical background in dairy cattle. According to these values, it was decided that the fit of the model was good.

Considering small sample sizes as 10-20, Logistic and Saturation growth models are more suitable than Allometric, Exponential and Incomplete gamma models for predicting body weight from body length measures. According to the linear model, the highest $\mathrm{R}^{2}$ and the lowest MSE is obtained from the group of 50 sample size. Considering 30-50 sample sizes group, according the $\mathrm{R}_{\text {adj }}^{2}$ $\mathrm{AIC}, \mathrm{BIC}$ and MEP values Incomplete model is more appropriate model than the others.

It is concluded that according to the small sample sizes (10-20), Logistic and Saturation growth models can be used to determine the body weight by using body length, on the other hand, Incomplete gamma model is more succesful to estimate body weight when sample size is bigger than 20 .

\section{Availabity of Data ANd Materials}

The author declares that data supporting the study findings are also available to the corresponding author.

\section{FUNDING SUPPORT}

The authors declared that there is no financial support.

\section{DeClaration OF CONFLICT OF INTEREST}

There was no conflict of interest in regards to author reporting his findings.

\section{REFERENCES}

1. Şahin A, Ulutaș Z, Karadavut U, Yıldırım A, Arslan S: Anadolu mandası malaklarında büyüme eğrisinin çeşitli doğrusal olmayan modeller kullanılarak karșılaștırılması. Kafkas Univ Vet Fak Derg, 20 (3): 357-362, 2014. DOI: $10.9775 / \mathrm{kvfd} .2013 .10171$

2. Macedo-Barragan M, Arredondo-Ruiz V, Haubi-Segura C, CastilloZamora P: Comparison of linear and nonlinear models to estimate body weight of Pelibuey ewes from body measurements. Trop Anim Health Prod, 53 (1): 56, 2021. DOI: 10.1007/s11250-020-02515-Z

3. Kshirsagar AM, Smith WB: Growth Curves.1-57, Marcel Dekker, USA 1995.

4. Efe E: Büyüme eğrileri. Doktora Tezi, Çukurova Üniv. Fen Bil. Enst, 1990.

5. Kocabaş Z, Kesici T, Eliçin A: Akkaraman, İvesi x Akkraman ve Malya x Akkaraman kuzularında büyüme eğrisi. Turk J Vet Anim Sci, 21 (3): 267275, 1997.

6. Perotto D, Cue RI, Lee AJ: Comparison of nonlinear functions for describing the growth curve of three genotypes of dairy cattle. Can J Anim Sci, 72, 773-782, 1992. DOI: 10.4141/cjas92-089

7. Tahtali Y, Sahin M, Bayyurt L: Comparison of different growth curve models in Romanov lambs. Kafkas Univ Vet Fak Derg, 26 (5): 609-615, 2020. DOI: $10.9775 / \mathrm{kvfd} .2020 .23954$

8. Draper NR, Smith H: Applied Regression Analysis. Vol. 26, 102-121, John Wiley \& Sons, USA, 1981.

9. Silveira FG, Silva FF, Carneiro PLS, Malhado CHM, Muniz JA: Cluster analysis applied to nonlinear regression models selection to growth curves of crossed lambs. Ciênc Rural, 41 (4): 692-698, 2011. DOI: 10.1590/ S0103-84782011000400024

10. Topal M, Macit M: Prediction of body weight from body measurements in Morkaraman sheep. J Appl Anim Res, 25, 97-100, 2004. DOI: 10.1080/ 09712119.2004 .9706484

11. Ibrahim A, Artama WT, Budisatria IGS, Yuniawan R, Atmoko BA, Widayanti R: Regression model analysis for prediction of body weight from body measurements in female Batur sheep of Banjarnegara District, Indonesia. Biodivers J Biol Divers, 22 (7): 2723-2730, 2021. DOI: 10.13057/ biodiv/d220721

12. Rather MA, Bashir I, Hamdani A, Khan NN, Ahangar SA, Nazki M: Prediction of body weight from linear body measurements in Kahmir Merino sheep. Adv Anim Vet Sci, 9 (2): 189-193, 2021. DOI: 10.17582/ journal.aavs/2021/9.2.189.193

13. Demir Y, Sahinler Z: Comparison of growth curves using non-linear models in Morkaraman male lambs subjected to different feeding regimes. $J$ Anim Plant Sci, 31 (3): 665-670, 2021.

14. Abd-Alameer AB, Nasr Noori AA: Prediction of lambs growth from milk production and its composition in Awassi sheep and description of growth curve of non-linear function. IOP Conf Ser: Earth Environ Sci, 910 (1): 012060, 2021. DOI:10.1088/1755-1315/910/1/012060

15. Bilgin OC, Esenbuga N, Macit M, Karaoglu M: Growth curve characteristics in Awassi and Morkaraman sheep, Part I: Comparison of nonlinear functions. Wool Tech Sheep Breed, 52, 1-7, 2004.

16. Ghahri B, Alijani S, Rafat SA, Nabavi R, Daghigh Kia H: Genetic appraisal of growth traits in Iranian native Ghezel sheep using random regression models. Turk J Vet Anim Sci, 43, 372-379, 2019. DOI: 10.3906/ vet-1704-73

17. Waheed HM, Moaeen-Ud-Din M, Khan MS, Saif-Ur-Rehman M, Nawaz-Ul-Rehman MS: Prediction of monthly body weight from body measurements in Beetal goats reared under field and farm conditions. $J$ Anim Plant Sci, 30, 25-31, 2020. DOI: 10.36899/JAPS.2020.1.0003

18. Raungprim T, Maitreejet W, Majarune S, Rattanatabtimtong S, Thongphrai P, Sarataphan N: Live weight estimation from body measurements of swamp buffaloes (Bubalus B. Carabanensis). Buffalo Bulletin, 40 (4): 583-590. 2021.

19. Topuz D: Lactation milk yield prediction with possibilistic logistic regression analysis. Kafkas Univ Vet Fak Derg, 27 (5): 547-557, 2021. DOI: $10.9775 / \mathrm{kvfd} .2020 .25171$ 